\title{
Social Representations of the Environment in Press Media ${ }^{1}$
}

\author{
Gislei Mocelin Polli ${ }^{2}$ \\ Universidade Tuiuti do Paraná, \\ Curitiba-PR, Brazil
}

\author{
Brigido Vizeu Camargo \\ Universidade Federal de Santa Catarina, \\ Florianópolis-SC, Brazil
}

\begin{abstract}
Environmental issues are given prominence in the media and scientific circles. From the 60's until early 2010 there were changes in the way people related to the environment, with a paradigm shift occurring regarding the environment. This study sought to identify the representational content disseminated by the press media on the environment in different periods. A qualitative survey was therefore conducted of documents, and data were obtained through texts published in a magazine with national circulation. The data were analyzed using the ALCESTE program with a Lexicographic Analysis. It was identified that the press media reflects the paradigm shifts, and publications dating from the late 60's are compatible with the old paradigm, evolving over time, and are now compatible with the new environmental paradigm. The results indicate that currently the environment needs care in all its aspects and lack of care creates global impacts.
\end{abstract}

Keywords: social psychology, social representation, communication

\section{Representações Sociais do Meio Ambiente na Mídia Impressa}

Resumo: Os temas ambientais recebem destaque na mídia de grande alcance e meios científicos. Da década de 1960 até os anos 2010, houve mudanças na forma das pessoas se relacionarem com o meio ambiente, houve uma mudança de paradigma ambiental. Este estudo buscou identificar o conteúdo representacional divulgado pela mídia impressa sobre o meio ambiente em diferentes períodos. Foi realizada uma pesquisa documental de caráter qualitativo, cujos dados foram obtidos através de textos publicados em uma revista de circulação nacional. Os dados foram analisados lexicograficamente através do programa Alceste. Foi identificado que a mídia impressa reflete as mudanças paradigmáticas, e as publicações que datam do final da década de 1960 são compatíveis com o paradigma antigo, evoluindo através do tempo, e atualmente são compatíveis com o novo paradigma ambiental. Os resultados indicam que atualmente o meio ambiente precisa de cuidados em todos seus aspectos e a falta de cuidado gera impactos globais.

Palavras-chave: psicologia social, representação social, comunicação

\section{Representaciones Sociales del Medio Ambiente en los Medios Impresos}

\begin{abstract}
Resumen: Las cuestiones ambientales dan prominencia en los medios de comunicación y los medios científicos. Desde los años 60 hasta los años 2010 se produjeron cambios en la forma en que las personas se relacionan con el medio. Este estudio trata de identificar el contenido representacional divulgado por los medios de comunicación impresos acerca del medio ambiente en diferentes períodos. Se realizó un estudio documental cualitativo, cuyos datos se obtuvieron a través de los textos publicados en una revista de circulación nacional. Se realizó un análisis lexicográfica con el programa ALCESTE. Se identificó que el material de impresión refleja los cambios de paradigma ambiental, y publicaciones que datan de finales de los años 60 son compatibles con el viejo paradigma, que evoluciona con el tiempo, y ahora son compatibles con el nuevo paradigma ambiental. Los resultados indican que, en la actualidad, el medio ambiente necesita atención en todos sus aspectos y la negligencia crea impactos globales.
\end{abstract}

Palabras clave: psicología social, representación social, comunicación

\section{Social Representation Theory}

Social representations are phenomena of daily life. When people think about relevant facts, taking a position, expressing and sharing thoughts through communication, they are creating or reproducing representations. Social representation theory seeks to explain and understand how the process

\footnotetext{
${ }^{1}$ Article derived from the doctoral dissertation of Gislei Mocelin Polli under the supervision of Brigido Vizeu Camargo, defended in 2012, in the Graduate Program in Psychology, of the Universidade Federal de Santa Catarina.

2 Correspondence address:

Gislei Mocelin Polli. Rua Francisco Guilherme Bahr, 289, apto 12, Tingui. CEP 82620-070. Curitiba-PR, Brazil. E-mail: gismocelin@gmail.com
}

of the creation of social thinking takes place, and how it is maintained or changed, among other factors.

It emerged in Europe, within the field of Social Psychology, with the publication of La Psychanalyse: Son Image et Son Publique by Serge Moscovici in 1961 in France (Moscovici, 2012). Social representation theory arose through the interest in understanding how collective thought is organized, as well as the content itself of thinking which is shared socially.

The social representations are activated in action in social life, and their elements constitute a knowledge which says something about the context, and which is characterized, therefore, as a form of knowledge which is elaborated and shared socially, and which results in a context common to 
a social group and in a knowledge of common knowledge, which in spite of being different from scientific knowledge may be influenced by this (Jodelet, 2001).

\section{Social Representations and Communication}

It is through communication that the social representations arise and are expressed and shared, gaining space in a given social group. Moscovici (2012), studying the social representation of psychoanalysis spread by the French press focused on the influence that mass communication exercises as an important process in the formation of social thought on a specific social object, in that specific case, psychoanalysis.

Mass communication is present in our routine. Rouquette (1986) explains the four phases of the penetration of a message: (a) exposure: when a person exposes herself or is exposed to a source of information, and becomes part of the public which receives the message; (b) reception: the person receives, from the information source, a message characterized by form and content; (c) treatment: the message is integrated into the individual's cognitive system through interpretation, classification, integration and retention this treatment depends as much on individual variables as on social variables; (d) interaction: this occurs through the relation with interlocutors, to whom the already-treated message is transmitted.

Moscovici (2012) explains the different modes of transmission of a media message. Such communication modalities determine the content in the form of the messages which are transmitted or received. These are: Diffusion, Propagation, and Propaganda.

Diffusion is the most extensive system of mass communication, and has the objective of transmitting information, without concern regarding reinforcing, influencing or convincing. In this communication system, the issuer seeks to establish a relationship of equality with the public, adapting to it. Although it is not a form of communication which aims to produce collective conducts, the diffusion can be efficacious.

The propagation, in its turn, is directed towards a particular public, with specific objectives and values. Propaganda has a regulatory function and an organizing function. It serves to regulate to the extent that it seeks to establish the identity of a group (Moscovici, 2012; Rouquette, 1986).

The texts used by journals with wide circulation, as with press, journalistic or televised texts, use diffusion as a mode of transmitting information. Among the means of dissemination of information with the greatest reach, one finds television, newspapers, magazines and the Internet.

The theory of social representations, since its appearance, has considered the influence of mass communication in the formation of the social representations, such that the inaugural study of the theory, undertaken by Serge Moscovici in 1961, dealt with the role of the press in the formation of the social representation of psychoanalysis among the French (Moscovici, 2012).

More recently, in Brazil, various studies have investigated the role of the media in the formation of social representations of different social objects (Bousfield \& Camargo, 2011; Corrêa, Gontijo, Assis, Carrieri, \& Melo, 2007; Porto, 2009; Teo, 2010). Some studies on the social representation of the environment recognize the role of means of mass communication in the formation of social thought on this subject (Bertoldo \& Bousfield, 2011; Calixto Flores, 2008; Kuhnen \& Becker, 2010; López, Avelar, Moreno, Beltrán, \& Estrada, 2008; Polli, Kuhnen, Azevedo, Fantin, \& Silva, 2009).

The emphasis which environmental themes receive through their broad dissemination in the means of mass communication have also been the study object of various fields of knowledge concerned with the impact of the dissemination of environmental themes on the population in general (Abreu \& Félix, 2008; Machado, 2008; Miguel, 2012).

However, studies focusing on the social representations of the environment spread by the means of mass communication in Brazil were not found in scientific journals. Considering the importance which the information spread by media with large circulation regarding a specific social object have in the formation of the social representations which circulate in our society, the lack of studies with this guideline indicates a gap in the knowledge regarding the socially-shared ways of thinking about the environment.

\section{Environmental Paradigms}

Historically, humanity has used nature to meet its needs for survival. It has been since the Industrial Revolution, however, that peoples' interactions with the environment have come to be characterized by the search for socioeconomic gains. Since that time, the indiscriminate use of nature and its elements has provoked reactions, such as global warming, the shortage of and pollution of water, floods and a wide variety of types of natural manifestations whose origins lie in human activity (Milfont, 2010).

Since the 1970s, a new view of the environment has gained space in society, which began with the United Nations Conference on the Human Environment, held in 1972, in Stockholm, Sweden. Until then, beliefs predominated holding that nature existed to meet human needs. These beliefs make up the so-called dominant social paradigm (Human Exemptionalism Paradigm - HEP), or anthropocentric view, in which the environment or nature is seen as a set of inert physical elements. It can and must be controlled by human beings, and serves to enable economic gains. Progress is considered necessary, regardless of the uses of the natural elements. This paradigm is linked to beliefs of growth, prosperity, abundance and progress. In this view, humanity is not part of the environment, but, rather, has the role of ruling it (Corral-Verdugo, 2011; Mezzomo \& Nascimento-Schulze, 2004). 
Economic and industrial development themselves put on the agenda a growing environmental concern, which gave rise to changes in the beliefs regarding nature and the environment. A new paradigm, based in the view that natural resources must be cared for, preserved, and used with consideration has gained space. The New Environmental Paradigm (NEP), or ecological view (Dunlap, Van Liére, Mertig, \& Jones, 2000) gradually came to substitute the until-then dominant paradigm.

The new paradigm has opened a path recognizing that humanity may confront - or is confronting - various problems related to person-environment interdependence, as it is based in the idea of inter-relation between human societies and the physical and natural environment, recognizing the human being as part of nature and not as a being placed above it. The new environmental paradigm raises the question of the notion of sustainability, through the use of natural resources without their exhaustion, and has popularized the renewal of the resources used (Pinheiro \& Gurgerl, 2011).

\section{Method}

\section{Sample}

Taking into consideration that social thought has been influenced by means of mass communication, this study proposes to undertake a documental analysis of articles dealing with the environmental issue, published in a magazine with a broad readership in Brazil.

The magazine to have its texts analyzed was VEJA, selected because of its high circulation, as it presents content of the same character as that vehicled by the television media, because it is a vehicle of diffusion (Moscovici, 2012), and because its texts - since the first issue produced in 1968 - are made available free of charge on the Internet.

The magazine analyzed has been published weekly since its first issue, dated September 11, 1968. The most recent issue analyzed in this study is dated April 25, 2012. In this interval, 2,266 editions of the magazine have been published. Considering the high number of publications, some editions were defined for analysis.

Initially, the periods of publication to be analyzed were defined. Three periods were chosen, the first period being defined as the oldest, the first issues published by the magazine; the third period is the most recent; and an intermediate period between the first and the most recent.

For each one of the periods, five years were defined for analysis. The magazine is published four to five times monthly, such that there are approximately 240 issues of the magazine over a five year period. As this volume of articles is fairly high, it was decided to use sampling. For each month of publication, one issue was selected at random, so as to make up 60 articles for each period, in a total of 180 articles analyzed.

The first criteria for choosing the issue to be analyzed was the random selection, and the second was the presence of articles related to the issue of the environment, such that one issue was selected, and following that, the magazine was read through digitally, so as to ascertain the presence of articles on this subject. If there was no article in the first issue, a second was selected, and so on in succession until an article on the environment was found. In cases in which a specific month had no article on this topic, that month was not counted, and a new month's issue was added to the end of the list, so as to make up 60 articles for each period. This criteria was used so as to ensure the same number of articles in each one of the periods.

The first period was based on the first publications of the magazine, starting in September 1968 and finishing in December 1973. The second period analyzed was of January 1997 to April 2002. The third period analyzed was the most recent, beginning in February 2007 and continuing through to April 2012.

\section{Instruments}

In order to gain access to the data, computers were used with access to the Internet, in order to access Veja magazine's online files. Furthermore, software was used for transforming images into text, given that some issues of the magazine are made available in image format. The program used was Abby Fine Reader, through a free demonstration version.

\section{Procedure}

Data collection. Data collection took place in May 2012. The data were collected from Veja magazine's digital holdings, with free access made available on the Internet.

Data analysis. The content of the articles selected was treated through a descending hierarchical lexical analysis undertaken using the ALCESTE (Analyse Lexicale par Contexte du'n Ensemble de Segments de Texte) program (Reinert, 1998).

The textual data, which can be the target of content analysis, originates in the written or transcribed language, such that this data can be collected through interviews, documental analysis, from texts in the media, open questions in questionnaires, and other techniques (Soares, 2005). In this case, data from magazine texts were used, making it, therefore, a documental analysis.

The ALCESTE program works with Initial Context Units (ICUs) which may be structured in different ways, depending on the nature of the data collected. The set of ICUs makes up the corpus of analysis. In the case of documental analysis, each ICU is formed by one selected article, such that the corpus of analysis was formed by 180 ICUs. Each ICU may be associated with different variables. For undertaking the Descending Hierarchical Classification (DHC), the variable considered was the period of publication of the article.

After the ICUs have been defined by the researcher, the ALCESTE program divides the corpus into segments of texts, most of which have approximately 3 lines. These are 
the Elementary Context Units (ECUs). When working with a high volume of textual data, as in documental analysis, the program divides parts of the text into sections, and each one of these parts forms a ECU.

The Descending Hierarchical Classification (DHC) makes possible a lexical analysis of the textual material, and generates contexts (lexical classes), characterized by a specific vocabulary and by segments of texts which have this vocabulary in common. The segments are classified as a function of their vocabularies, and their set is divided by the frequency of the reduced forms (Castro, Koelzer, Camargo \& Bousfield, 2014).

In the Descending Hierarchical Classification (DHC), each class is formed of various segments of text which are classified according to the distribution of the vocabulary. The classes generated based on the descending hierarchical classification present words and the contexts in which these words gain meaning, and may indicate social representations regarding the object of interest (Camargo \& Justo, 2013).

\section{Results}

The corpus for analysis of the social representation of the environment was made up of 180 articles, which gave rise to 180 Initial Context Units (ICU). The corpus was divided into 3,715 Elementary Context Units (ECUs), of which $83 \%$ were considered in the DHC, with 3,090 ECUs analyzed. All the words with frequency below four were excluded from the analysis, such that 5,592 words were analyzed, with a mean occurrence of 8 . In producing the dendrogram, a Chi-squared value was selected four times greater than the minimum value $\left(\chi^{2} \geq 15.36\right)$, in order to work with a lower margin of error in each association of the word with its class. The minimum frequency considered for producing the dendrogram was 30 , so that only the words which were most characteristic of each class would be presented graphically. The mean frequency of each word, and the Chi-square value, are expressed in the dendrogram, as shown in Figure 1.

The descending hierarchical classification of the corpus regarding the social representations of the environment in the press media gave rise to 7 classes. In Figure 1, it is possible to observe that the first partition of the corpus opposes class 7 to the remaining classes. The second partition demonstrates the opposition between classes 1, 5 and 6 in relation to classes 2 , 3 and 4 . The third partition opposes class 1 to classes 5 and 6 , which oppose each other in the fifth partition. The fourth partition opposes class 2 to classes 3 and 4, which oppose each other in the sixth partition of the corpus.

In each one of the classes, the following were presented: the title of the class; the number of ECUs which made it up; the associated variables described, and the words which make them up, with the respective frequencies and Chisquare values.

\section{Class 1 - Environmental Disasters}

Class 1 was made up of 890 ECUs, which corresponds to $29 \%$ of the entire corpus. It is representative of the first period investigated (1968 to 1973). Its content is grouped around words such as drought, rains, North-east, losing, dying, flood, and hunger, among others. Its content deals with environmental disasters and catastrophes.

This class presents a social representation of the environment geared towards concern with catastrophes such as droughts, floods, hurricanes and their consequences, such as hunger, thirst and deaths. It is an informative class, in which the occurrences are treated as natural. Some excerpts from the responses found illustrate the discourse present in this class:

At the beginning of the week, 50 heads of families requested food and work from the mayor of Mombaça, land of the governor of the state of Ceará, Plácido Castelo. They threatened to return, if it did not rain in two days, to sack the marketplace. They did indeed return; this time numbering over one thousand people. (April 1970)

\section{Class 5 - Contamination of Waters}

Class 5 was made up of 259 ECUs, corresponding to $8 \%$ of the entire corpus. It is representative of the first period investigated (1968 to 1973). Its content is grouped around words such as beach, sewage, vinasse, fish, polluted, oxygen, bay, among others. Its content deals with the pollution of water by sewage and garbage.

This class deals with the environment based on concerns about the contamination of water by industrial waste, sewage and garbage. The consequences of the pollution for subaquatic life and also the need to create alternatives to the direct disposal of waste in rivers, the sea and lagoons are indicated. An excerpt of the responses found illustrates the discourse present in this class:

The vinasse, in contact with the water, removes from the latter almost all of its oxygen, causing the death of fish and aquatic plants. In Rio Grande do Sul, the Gravataí river and the dos Sinos river are true open-air sewers, strange currents where there are feces, industrial waste, and remains from abattoirs. (May 1970)

\section{Class 6 - Water and Supply}

Class 6 was made up of 205 ECUs, which corresponds to $7 \%$ of the entire corpus. It is representative of the first period investigated (1968 to 1973). Its content is grouped around words such as river, water, city, works, projects, reservoir, system, government, and basic sanitation, among others. Its content refers to the supply of water. 
Polli, G. M., \& Camargo, B. V. (2015). Environment's Social Representation.

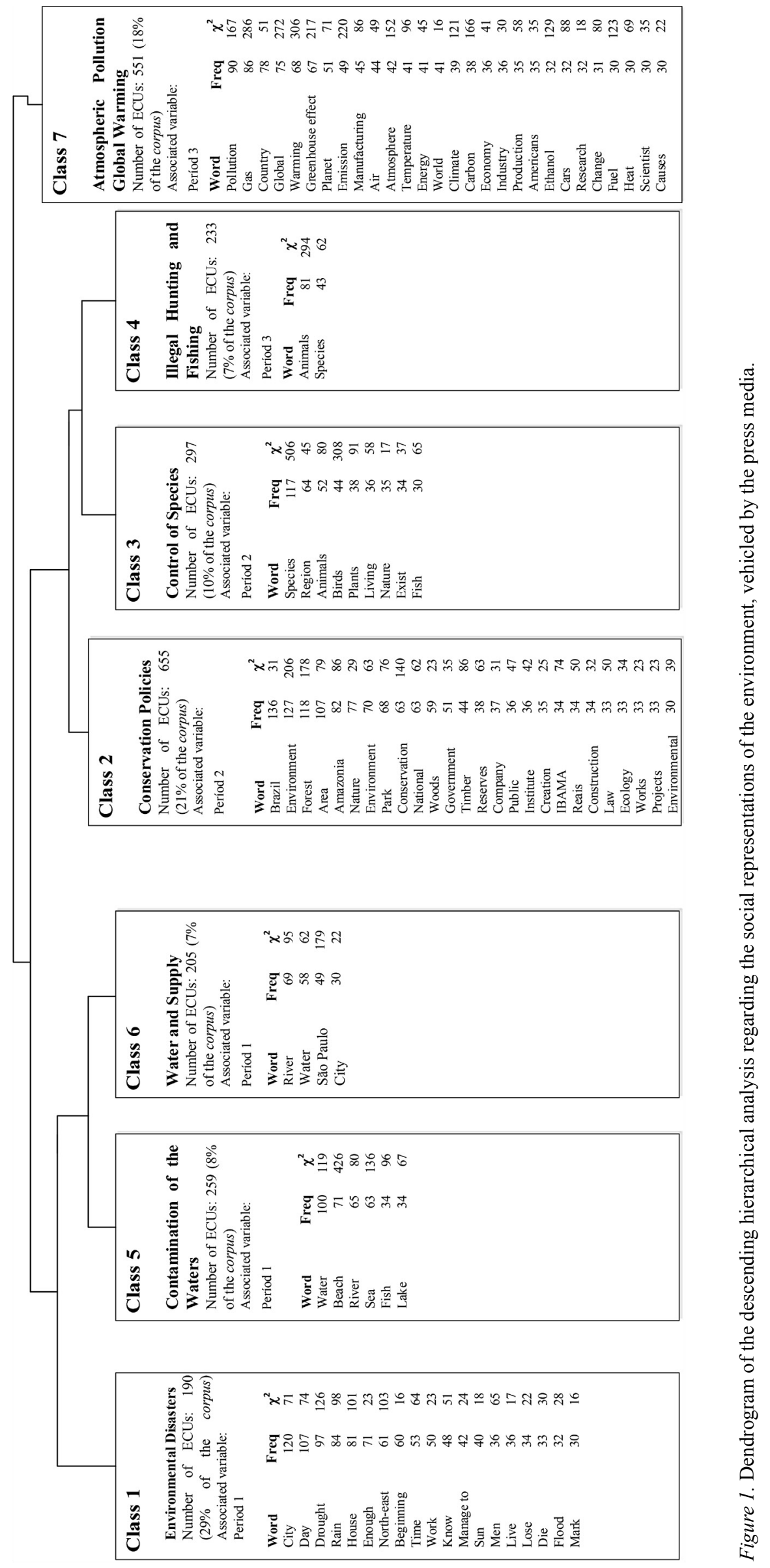


This class refers to the supply of water and to basic sanitation works for viabilizing or improving this supply. Although some specific situations from other cities are cited in some materials, most of them refer to works in the city of São Paulo. One excerpt from the responses found illustrates the discourse present in this class:

And in spite of this diversification, its advantages are clear. Even in numbers: only one pumping station, 18 kilometers of piping and 2.1 of tunnels, as opposed to five stations, 100 kilometers of pipes and 12.6 of tunnels in the project selected by São Paulo's Department of Works and metropolitan sanitation company. (February 1971)

\section{Class 2 - Policies for Preservation}

Class 2 was made up of 655 ECUs, which corresponds to $21 \%$ of the entire corpus. It is representative of the second period investigated (1997 to 2002). Its content is grouped around words such as Brazil, environment, forests, nature, conservation, government, public, IBAMA (Trans. note: Brazilian's Institute of Environment and Renewable Resources, the administrative arm of the Brazilian Ministry of the Environment.), and projects, among others. Its content deals with governmental activities for the preservation of the environment.

This class raises a social representation of the environment geared towards the responsibilization of the government for the care for the environment. This class contains concerns about preservation of the environment, but emphasizes governmental actions in order to achieve this end. One excerpt from the responses found illustrates the discourse present in this class: "The Ministry of the Environment calculates that logging activity is responsible for a further $2000 \mathrm{~km}^{2}$ per year of forest lost. (...) The government attributes the stabilizing of the devastation to the increase in inspection activities" (April 2000).

\section{Class 3 - Control of Species}

Class 3 was made up of 197 ECUs, which corresponds to $10 \%$ of the entire corpus. It is representative of the second period (1997 to 2002). Its content is grouped around words such as species, region, animals, birds, plants, fish, fauna, and ecosystem, among others. Its content deals with animal and vegetable species, their habitats, and balance.

Class 3 deals with aspects of the environment which are related to the balance between the species and their habitats. It is an informative class, in which interactions between the animals and the environment in which they live are described. The balance of the flora is also emphasized. One excerpt from the responses found illustrates the discourse present in this class: "The archipelago of Fernando de Noronha is one such place. There, a type of lizard brought from the semi-arid
North-east has proliferated vertiginously, in the absence of any predators" (October 2000).

\section{Class 4 - Illegal Hunting and Fishing}

Class 4 was made up of 233 ECUs, which corresponds to $7 \%$ of the entire corpus. It is representative of the third period investigated (2007 to 2012). Its content is grouped around words such as animals, gorillas, tiger, jaguar, hunting, humans, hunter, and Africa, among others. Its content deals with illegal hunting and fishing.

This class is concerned with species which suffer because of illegal hunting and fishing, with the combat against such practices and with the relevant legislation, in addition to containing descriptions of specific cases. One excerpt from the responses found illustrates the discourse present in this class: "The next victim. Illegal fishing has reduced the stocks of the Atlantic bluefin tuna to $10 \%$ of what they were, and the Japanese fear the end of their favorite dish" (July 2007).

\section{Class 7 - Atmospheric Pollution and Global Warming}

Class 7 was made up of 551 ECUs, which corresponds to $18 \%$ of the entire corpus. It is representative of the third period investigated (2007 to 2012). Its content is grouped around words such as warming, global, emissions, greenhouse effect, pollution, carbon, atmosphere, ethanol, and climactic, among others. This class refers to atmospheric pollution and its consequences.

This class deals with the emission of polluting gases and their consequences, such as global warming, and greenhouse effect. Some texts bring examples of alternatives to the excessive emission of pollutants. One excerpt of the responses found illustrates the discourse present in this class:

In certain places of the Sahara desert, where the thermal gradients are normally the broadest on the planet, the mean variation is of $60^{\circ}$. The obvious suspect for explaining the high-temperature in Russia is global warming. Environmentalists have taken advantage of the opportunity to protest against the emissions of greenhouse gases in that country, the world's third greatest polluter. (August 2010)

\section{The Social Representation of the Environment Disseminated by the Press Media in Different Periods}

The analysis undertaken with the help of the ALCESTE program made it possible to identify important differences in the information disseminated regarding the environment in different periods. The Descending Hierarchical Classification (DHC) generated 7 classes, of which 3 were characteristic of the first period (1968 to 1973), 2 were characteristic of the second period (1997 to 2002), and 2 were characteristic of the third period (2008 to 2012). 
For the purposes of this study, the text content of the articles analyzed was considered as a means of expression of the social representation of the environment. The documental study was the means found for identifying the social representations of the environment circulating in Brazilian society in periods different from the present time.

After such considerations, and bearing in mind the results of the DHC, one can speak of 3 different social representations found in the 3 different periods of time analyzed. In order to be able to talk about a social representation expressed through the classes resulting from the DHC, it is necessary to consider the classes with the greatest content, it being the case that the smaller classes provide additional information, but do not configure a social representation different from that represented by the larger class.

Thus, it becomes possible to present the social representation of the environment circulating in Brazilian society at the end of the 1960s and beginning of the 1970s and that characteristic of the end of the 1990s and beginning of the 2000 's, as well as a social representation of the environment from the most recent five years, from 2008 to 2012.

Between 1968 and 1973, the representational content linked to the environment revolved around environmental disasters. The main class of the period deals with this issue, addressing articles on floods, droughts, landslides, hurricanes, etc, as well as the consequences in peoples' lives. The content of the other classes fits in the same representational logic, as when class number 5 deals with contamination of water by garbage and waste, the concern is geared also towards the consequences for the supply and quality of the water, an issue also found in class 6 .

In this period, the main expression of the environment was the excess or lack of water which caused most disasters. It was water that suffered through the disposal of waste, with works for regulating the supply of water in order to try to minimize the problems caused by its abundance (torrential rains), its scarcity (drought), or its contamination (garbage and waste). It is important to take into account that the global impacts of the problem were not considered; only the local consequences, which directly affected the life of each citizen.

In the second period investigated, from 1997 to 2002, the social representation of the environment is represented by class number 2, which deals with the creation of laws and policies for preserving the environment. Class 3, also characteristic of this period, is more descriptive of situations in which some animals and vegetation are identified and classified, without adding much to the way of thinking about the environment, apart from the fact that - in addition to water - living beings are emphasized as part of the environment in this period.

In this period, the environment comes to be considered as something to be preserved. It is sought to avoid deforestation through relevant legislation and denunciations, and areas of environmental preservation are created in greater numbers. Environmental concern is installed, although still directed towards local issues; the global impact is not emphasized.
Class number 7 allows the identification of the representational content regarding the environment at the present time. Atmospheric pollution and global warming are the items emphasized most, and the concern with preserving species is manifested through class 4 . Through this, one can note a transition from the local thinking, characteristic of the first and second period, present also in class 4 of the third period, to a more global thinking, characteristic of the third period.

Nowadays, the global impacts of the environmental crisis which the world faces are considered, as are climate changes arising from global warming. The origin of the atmospheric pollution is questioned, explanations and alternatives are sought, such as clean energy and the use of less-polluting cars. The individual part in the origin of the problem is considered, and the need for behavioral change emerges as an alternative.

Comparing the three periods, one can state that in the initial period, the environment was seen as something which acted against people, through an uncontrollable force, the forces of nature. Some works of infrastructure, it was held, would be able to mitigate some consequences at the local level. Some decades later, in the intermediate period, the role of the government was recognized in relation to the care for the environment, through laws and policies on environmental conservation, although still at a local level. At the time of writing, it seems that there has been a leap forwards in how people think about the environment; it is today seen as something which affects everybody in the same way, with the consequences of the modern lifestyle resulting in destruction which is invisible, but which affects everybody indiscriminately.

\section{Discussion}

Some studies on social representations have sought to identify the influence of the means of mass communication in the forming of the social representations of different social objects (Aléssio, Apostolidis, \& Santos, 2008; Corrêa, Gontijo, Assis, Carrieri, \& Melo, 2007; Porto, 2009; Teo, 2010). Such studies emphasize the importance which mainstream media exercises in the formation of the social representations of a wide variety of social objects, among which one finds the environment.

Studies directed towards the social representations of the environment, or towards environmental aspects disseminated through the means of mass communication in Brazil, were not identified in scientific journals. However, the issue of the environment has been increasingly present in the media discourse (Abreu \& Félix, 2008; Bertoldo \& Bousfield, 2011; Miguel, 2012), and the large volume of information on the environment and environmental aspects which affect the population, thanks to the wide coverage of means of mass communication, have become an important part in the formation of the social representations.

The analysis of the texts published made it possible to identify three distinct social representations regarding the environment, each one characteristic of a different period. In the first years of the magazine's circulation, from 1968 
onwards, a social representation of the environment was present which was compatible with the anthropocentric view. It is important to take into consideration that this was the period in which the Stockholm conference was being planned, being held in 1972. It was the beginning of global concerns regarding the environment, concerns which were slow to reach Brazil, where they began to gain space after the Rio 92 conference (Guimarães \& Fontoura, 2012), which may have influenced the changes identified in the discourse, identified by the media in the following years.

At the end of the decade of the 1990s, the social representation of the environment disseminated by the magazine still presents content compatible with the anthropocentric view but the ecological view seems to have been gaining space. In the most recent period, the ecological paradigm seems to have totally overthrown the anthropocentric paradigm, and the conservationist discourse is heavily emphasized in the articles analyzed. However, actions which are compatible with the old paradigm are identified, and are heavily criticized.

Although the U.N. Rio +20 conference was a previous proposal, it is possible to say that this may be considered a consequence of this change in the social thinking regarding the environment. The 1972 conference had its role in placing environmental concerns on the agenda, while the 1992 conference, held in Brazil, placed Brazil within this issue, but its outcome, undertaken in the Rio +20 conference, seemed to be something which had its origin in the social thinking, and not something destined to influence how people think about the environment.

One can state that the first two conferences placed environmental concerns on the agenda outside Brazil, in 1972, being definitively established in Brazil in 1992, but that the 2012 conference served to respond to such concerns, this time already present in the social thinking of the Brazilian population.

Such occurrences are reflected in the way of thinking about the environment, beginning with the environmentalists and authorities involved directly in the conferences, but which reached the population in general through the dissemination undertaken by the media on a world scale. The 1972, 2002 and 2012 conferences are not decontextualized from the social context, and are the results of the environmental demands on political, social and economic levels. They respond to the interests of the environment, of the environmentalists, and of the authorities; but their consequences, projected through the means of mass communication, affect everybody, influencing the social representations of the environment of the entire population which has access to such information. In this way, the context changes, information is altered, and the social representations are re-organized in accordance with the social discourse which comes to circulate in society (Jodelet, 2001, 2002; Moscovici, 2012; Rouquete, 1986).

Knowing the social representations of the environment which circulate in society at different historical times allows us to understand the different behaviors adopted in relation to natural resources over time, in addition to providing indications on what to expect of human relations with the environment in years to come.

It also allows the process of the change of a social representation - which occurs slowly - to be identified, understood and studied, providing theoretical contributions on this vast field of study, which is the field of social representations.

In investigating the social representations of the environment in different epochs, and relating to changes in social thinking through their relation with the change of environmental paradigm which circulates in society over time, it is possible for the phenomenon of social representations to be studied through its anchoring in the social and historical context, recognizing the social character of the phenomenon, in addition to its individual cognitive characteristics.

The results found confirm the idea that the environmental discourse at the end of the 1960s and beginning of the 1970 s was compatible with the dominant paradigm, that is, the anthropocentric view. With time, the new environmental paradigm gained strength, and at the end of the 1990s, environmental concern was already part of the media discourse, although the impacts were still considered at the local level. In the most recent five years of publications on the environment, the ecological paradigm has gained strength, and concerns regarding the environment currently strongly permeate the media discourse.

This study did not aim to analyze different media, being restricted to the press media, which indicates both a limitation of the present study and an indication for future studies. It would be interesting to ascertain the type of content vehicled by other types of media over time, in order to identify the influence which different forms of information exercise on social thinking.

Studies such as this make it possible for information which cannot be accessed directly to be inferred based on the discourse disseminated by the media in a specified epoch or historical period. As a result, the present study presents a methodological contribution for studies with similar objectives, which aim to identify the historic evolution of the social representations of some relevant social object.

\section{References}

Abreu, G. X., \& Félix, J. A. B. (2008). O meio ambiente na mídia: Um estudo de caso do jornal de maior circulação de Brasília. Universitas: Arquitetura e Comunicação Social, 5(1-2), 51-68. doi:10.5102/uc.v5i1.676

Aléssio, R. L. S., Apostolidis, T., \& Santos, M. F. S. (2008). Entre o aborto e a pesquisa: O embrião na imprensa brasileira. Psicologia: Reflexão e Crítica, 21(3), 455-463. doi:10.1590/S0102-79722008000300014

Bertoldo, R. B., \& Bousfield, A. B. S. (2011). Représentations sociales du changement climatique: Effets de contexte et d'implication. Temas em Psicologia, 19(1), 121-137.

Bousfield, A. B., \& Camargo, B. V. (2011). Divulgação do conhecimento científico sobre AIDS e representações sociais. Acta Colombiana de Psicología, 14(1), 31-45. 
Calixto Flores, R. (2008). Representaciones sociales del medio ambiente. Perfiles Educativos, 30(120), 33-62.

Camargo, B. V., \& Justo, A. M. (2013). IRAMUTEQ: Um software gratuito para análise de dados textuais. Temas em Psicologia, 21(2), 513-518. doi:10.9788/TP2013.2-16

Castro, A., Koelzer, L. P., Camargo, B. V., \& Bousfield, A. B. S. (2014). Representações sociais na internet sobre cotas para negros em universidades federais. Cadernos de Pesquisa Interdisciplinar em Ciências Humanas, 15(106), 202-220. doi:10.5007/1984-8951.2014v15n106p202

Corral-Verdugo, V. (2011). Introduction to the special issue on sustainable behavior. International Journal of Hispanic Psychology, 4(1), 1-3.

Corrêa, A. M. H., Gontijo, M. C. L., Assis, L. B., Carrieri, A. P., \& Melo, M. C. O. L. (2007). Soldadinhosde-chumbo e bonecas: Representações sociais do masculino e feminino em jornais de empresas. Revista de Administração Contemporânea, 11(2), 191-211. doi:10.1590/S1415-65552007000200011

Dunlap, R. E., Van Liere, K. D., Mertig, A. G., \& Jones, R. E. (2000). Measuring endorsement of the new ecological paradigm: A revised NEP Scale. Journal of Social Issues, 56(3), 425-442. doi:10.1111/0022-4537.00176

Guimarães, R. P., \& Fontoura, Y. S. R. (2012). Rio+20 ou Rio-20?: Crônica de um fracasso anunciado. Ambiente \& Sociedade, 15(3), 19-39. doi:10.1590/S1414-753X2012000300003

Jodelet, D. (2001). Representações sociais: Um domínio em expansão. In D. Jodelet (Org.), As representações sociais (L. Ulup, Trans., pp. 17-44). Rio de Janeiro, RJ: Ed. UERJ. Jodelet, D. (2002). A cidade e a memória. In V. del Rio, C. R. Duarte, \& P. A. Rheingantz (Orgs.), Projeto do lugar: Colaboração entre psicologia, arquitetura e urbanismo (pp. 31-43). Rio de Janeiro, RJ: Contra Capa.

Kuhnen, A., \& Becker, S. M. S. (2010). Psicologia e meio ambiente: Como jovens e adultos representam a água de abastecimento. Psico, 41(2), 160-167.

Machado, C. A. (2008). Filmes de ficção científica como mediadores de conceitos relativos ao meio ambiente. Ciência \& Educação (Bauru), 14(2), 283-294. doi:10.1590/S1516-73132008000200007

Mezzomo, J., \& Nascimento-Schulze, C. M. (2004). O impacto de uma exposição científica nas representações sociais sobre meio ambiente: Um estudo com alunos do ensino médio. Comunicação \& Sociedade, 6, 151-170. doi:10.17231/comsoc.6(2004).1233

Miguel, K. (2012). Os paradigmas da imprensa na cobertura das políticas ambientais. Intercom: Revista Brasileira de Ciências da Comunicação, 35(1), 111-131. doi:10.1590/S1809-58442012000100007

Milfont, T. L. (2010). The psychological meaning of preservation and utilization attitudes: A study using the natural semantic network technique. Psyecology, 1(1), 123-136. doi:10.1174/217119710790709559

Moscovici, S. (2012). A psicanálise, sua imagem e seu público (S. Fuhrman, Trans.). Petrópolis, RJ: Vozes.
Pinheiro, J. Q., \& Gurgel, F. F. (2011). Perspectiva temporal. In S. Cavalcante \& G. A. Elali (Orgs.), Temas básicos em psicologia ambiental (pp. 267-280). Petrópolis, RJ: Vozes.

Polli, G. M., \& Camargo, B. V. (2013). Meio ambiente e água sob a perspectiva da teoria das representações sociais. Psicologia: Ciência e Profissão, 33(2), 256-271. doi:10.1590/S1414-98932013000200002

Polli, G. M., \& Kuhnen, A. (2011). Possibilidades de uso da teoria das representações sociais para os estudos pessoa-ambiente. Estudos de Psicologia (Natal), 16(1), 57-64. doi:10.1590/S1413-294X2011000100008

Polli, G. M., Kuhnen, A., Azevedo, E. G., Fantin, J., \& Silva, R. F. G. (2009). Representações sociais da água em Santa Catarina. Psicologia em Estudo, 14(3), 529-536. doi:10.1590/S1413-73722009000300014

Porto, M. S. G. (2009). Mídia, segurança pública e representações sociais. Tempo Social, 21(2), 211-233. doi:10.1590/S0103-20702009000200010

Reinert, M. (1998). Alceste: Analyse de données textuelles. Toulouse, France: Image.

Rouquette, M. L. (1986). La comunicación de masas. In S. Moscovici (Coord.), Psicología social (D. Rosenbaum, Trans., Vol. 2, pp. 627-647). Barcelona, Spain: Paidós.

Soares, C. C. C. (2005). Em torno do pensamento social e do conhecimento do senso comum. A aplicação da metodologia Alceste em contextos discursivos distintos. In A. S. P. Moreira, B. V. Camargo, J. C. Jesuíno, \& S. M. Nóbrega (Orgs.), Perspectivas teórico-metodológicas em representações sociais (pp. 541-572). João Pessoa, PB: Editora Universitária UFPB.

Teo, C. R. P. A. (2010). Discursos e a construção do senso comum sobre alimentação a partir de uma revista feminina. Saúde e Sociedade, 19(2), 333-346. doi:10.1590/S0104-12902010000200010

Torres López, T. M., Soltero Avelar, R., Pando Moreno, M., Aranda Beltrán, C., \& Salazar Estrada, J. G. (2008). Vida, frescura y limpieza: Representaciones sociales del agua desde el punto de vista de adolescentes y de padres de familia. Medio Ambiente y Comportamiento Humano, 9(1-2), 171-195.

Gislei Mocelin Polli is a Professor of the Universidade Tuiuti do Paraná.

Brigido Vizeu Camargo is Full Professor of the Centro de Filosofia e Ciências Humanas, Universidade Federal de Santa Catarina.

Received: Aug. 18, 2013 1st Revision: Jan. 9, 2015 Approved: Mar. 13, 2015

How to cite this article:

Polli, G. M., \& Camargo, B. V.(2015). Social representations of the environment in press media. Paidéia (Ribeirão Preto), 25(61), 261-269. doi:10.1590/1982-43272561201514 